\title{
AZO-HYDRAZO TAUTOMERISM: FURTHER EVIDENCE BASED ON POLAROGRAPHIC REDUCTION AND ACIDITY FUNCTION OF SOME HETEROCYCLIC COMPOUNDS CONTAINING OXIMINO-GROUP
}

\author{
By
}

\author{
Ahlam M. A. Helmy, AlaA El-Shafei, M. A. Migahed AND M. A. Morsi
}

Dept. of Chemistry, Faculty of Science, Mansoura University, Mansoura-Egypt

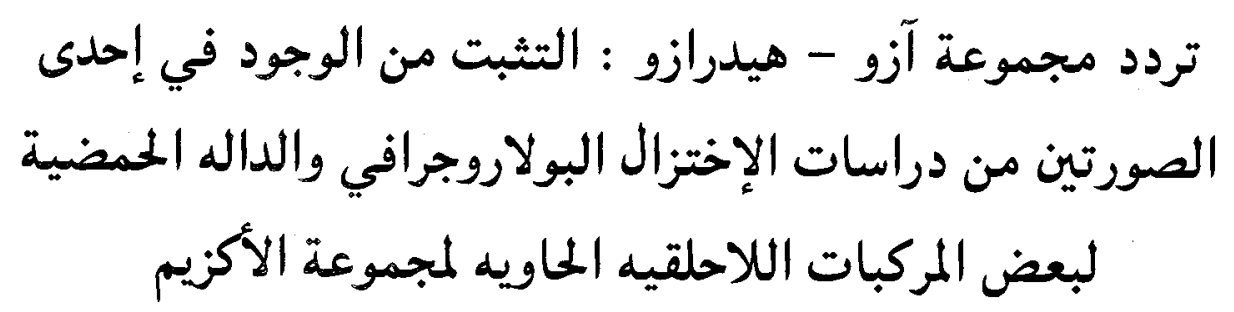

أحلام عباس حلمي و علاء الثافعي و محمد مجاهد و محمد علي مرسي

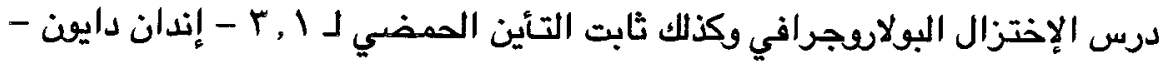

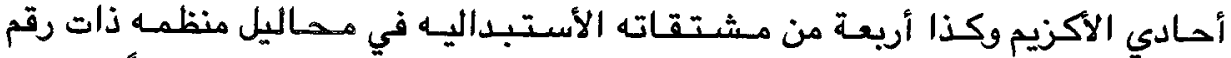

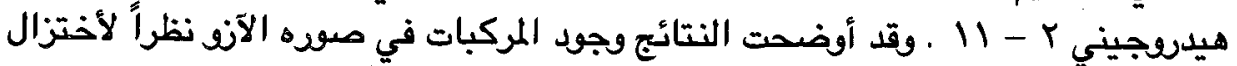

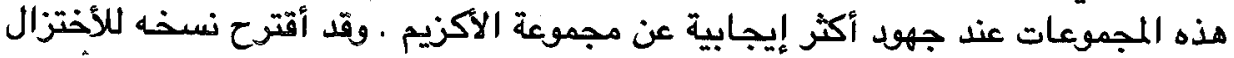

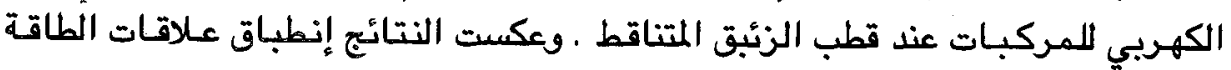

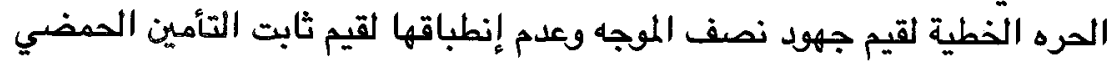

Key Words: Polarogrphy, Azo-hydrazo tautomerism, Heterocyclic compounds, Oximino-group.

\section{ABSTRACT}

Potentiometric pKa and polarographic behaviour of 1,3-indandione-monoxime-2-phenyl azo and four of its substituted derivatives were investigated in buffer solution of $\mathrm{pH} \sim 2-12$. The results showed that the compounds are in the azo-form, where its reduction wave precedes that of the oxime. A mechanism for the electrodic processes was proposed. Half-wave potentials showed fair correlation with Hammett's s constants while pKa is practically independent.

\section{INTRODUCTION}

The conflict of azo-hydrazo tautomerism in aqueous media has been dealt polarographically. An uptake of $2 \mathrm{e}$ in a reversible wave, by compounds capable of existing in both tautomeric forms is taken as an azo form reducing according to the following reaction[1-6].

\section{$\mathrm{R}_{1}-\mathrm{N}=\mathrm{N}-\mathrm{R}_{2}+2 \mathrm{H}^{+} \rightleftharpoons \mathrm{R}_{1}-\mathrm{NH}-\mathrm{NH}-\mathrm{R}_{2}$}

If the reduction of the molecule under investigation consumes $4 \mathrm{e}$, one should be cautious since differentiation between azo/hydrazo tautomeric system on the basis of $E_{1 / 2}$ can be misleading[7-12]. In such cases the behaviour of the nitro substituent in any location of the molecule has been reported to discriminate both tautomeric forms. The importance of the nitro derivative lies in the fact that literature survey of an azo compound containing a nitro substituent the $-\mathrm{N}=\mathrm{N}$ - group is reduced before the nitro $[3,7,8]$ group, while if a hydrazone form, $\mathrm{C}=\mathrm{N}-\mathrm{NH}$ - prevails the opposite reduction sequence occurs [9-11]. In a previous work we aimed to approach this point through studying the effect of polarographically active group (namely oxime)[12]. The results showed that in case of acyclic compound the oxime group is reduced first followed by a hydrazone (and not azo) group. Going in this direction it seemed to us worthwhile to investigate the role of the oxime group in conjunction with an azo/hydrazo group in a cyclic compound(I).

$$
\begin{aligned}
& \text { Of } \\
& I \\
& \begin{array}{rlrl}
\mathrm{R}: \mathrm{a} & =\mathrm{H} & \mathrm{b} & =\mathrm{P}-\mathrm{CH}_{3} \\
\mathrm{c} & =\mathrm{P}-\mathrm{OCH} \\
\mathrm{e} & =\mathrm{m}-\mathrm{NO}_{2} & & \mathrm{~d}=\mathrm{P}-\mathrm{Cl}
\end{array}
\end{aligned}
$$


The role of substituent, particularly the nitro derivative on the ease of reduction and acid-base equilibrium was also examined to evaluate the fidelity of applying LFER to the compounds under consideration.

\section{EXPERIMENTAL}

\section{Organic Syntheses}

The parent compound Ia was prepared following procedures described by Gudriniece and Vanagas[13] by coupling diazotized aniline with 1,3-indandione whereby 2 phenylazo 1,3-indandione is formed which on recrystallization from alcohol separates in fine lustrous deep brown crystals, m.p. $192^{\circ} \mathrm{C}$. The latter is then refluxed with hydroxylamine hydrochloride in alcohol for $2 \mathrm{hrs}$. After cooling Ia is separated, filtered and recrystallized from alcohol whereby Ia (2-phenyl azo-1,3-indandione monoxime) is obtained, $\mathrm{m}$. p. $264-265^{\circ} \mathrm{C}$. Following similar procedures compounds $\mathrm{I}_{\mathrm{b}-\mathrm{e}}$ were obtained by coupling the respective diazotized substituted aniline with 1,3-indanedione. Purity credit of the products was checked by microelemental analyses and TLC of the recrystallized products.

\section{Polarographic Investigation Apparatus}

Polarograms were recorded with a pen type recording polarograph (E 506 Metrohm, Switzerland). The capillary possessed the following characteristics in $\mathrm{H}_{2} \mathrm{O}$ open circuit: $\mathrm{t}=4.6 \mathrm{~s} \mathrm{drop}^{-1}, \mathrm{~m}=1.43 \mathrm{mg} \mathrm{s}^{-1}$ for $\mathrm{h}=40 \mathrm{~cm}$.

\section{Solution}

Stock solution $\left(10^{-3} \mathrm{~mol} \mathrm{~L}^{-1}\right)$ was prepared by dissolving an accurately weighed quantity of material in the appropriate volume of absolute ethanol. Due to the limited solubility of the $m-\mathrm{NO}_{2}$ derivative (le), the material was dissolved first in $5 \mathrm{ml}$ of DMF. Britton-Robinson modified universal buffers $[14,15]$ were used as supporting electrolyte.

\section{Measurements}

All experiments were carried out at $25 \pm 2^{\circ} \mathrm{C}$. The $\mathrm{E}_{1 / 2}$ was measured graphically and expressed $v s$ SCE with an accuracy of $\pm 5 \mathrm{mV}$. The solution $\mathrm{pH}$ was measured directly after each polarogrpahic run using glass electrode. The later was previously calibrated in ethanolic solutions following the procedures outlined by van Uitert and Hass[16].

\section{Procedure}

Ethanol $(6 \mathrm{ml})$ and the appropriate buffer solution (12 $\mathrm{ml}$ ) were introduced in the polarographic cell and deaerated with a stream of purified nitrogen for $12 \mathrm{~min}$. The calculated amount of stock solution $(2 \mathrm{ml})$ was then introduced into the cell so that the final concentration of depolarizer was $10^{-4} \mathrm{M}$ in $20 \mathrm{~cm}^{3}$ of $40 \%$ (V/V) ethanolic buffer.

\section{Determination of the number of electrons (n)}

Controlled potential electrolysis (cpe) was carried out on $200 \mathrm{ml}$ of $10^{-2} \mathrm{~mol} \mathrm{~L}^{-1}$ of Ia at $\mathrm{pH} 4.2$ which is $40 \%(\mathrm{~V} / \mathrm{V})$ ethanolic buffer. The electrolysis cell was $250 \mathrm{ml}$ conical flask with a working area of $\sim 50 \mathrm{~cm}^{2}$ in which the reference and auxilllary eletrodes and gas inlet were added through a cork. The potential was controlled at $0.060 \mathrm{~V}$ vs. SCE (i.e. on the limiting current plateau of wave a). Progress of electrolysis was followed by recording the decrease in current with time and the number of electrons involved in the electrode process was computed from i-t curves following the method outlined by Lingane[17]. For wave (a) the number of electrons was calculated and found to be 3.87 $(n=4)$. Comparison of the wave-heights of waves (a) and (b) showed that wave (b) is reduced in $4 \mathrm{e}$ wave. After complete electrolysis the cell was disconnected and aniline was detected in the electrolysed solution using the anthranilic acid spot test[18].

\section{Determination of apparent dissociation constant by potentiometry}

A freshly prepared stock solution of $10^{-3} \mathrm{~mol} \mathrm{~L}^{-1}$ (Ia-e) in $20 \mathrm{ml}$ ethanol was placed in $100 \mathrm{ml}$ beaker, diluted to 40 $\mathrm{ml}$ with distilled water so that the final concentration of the studied compound is $5 \times 10^{-4} \mathrm{~mol} \mathrm{~L}^{-1}$ in $50 \% \mathrm{~V} / \mathrm{V}$ ethanolic aqueous solution. The latter was then titrated against $10^{-2} \mathrm{~mol} \mathrm{~L}^{-1}$ free-carbonate sodium hydroxide solution with continuous stirring. The constant $\mathrm{pH}$ after each base addition was read on a digital $\mathrm{pH}$ meter (HANNA HI 9017 microprocessor) accurate to $\pm 0.01 \mathrm{pH}$ unit. The pKa was then calculated using the well known Henderson-

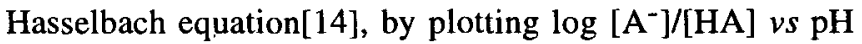
values. The intersection of the straight line with the $\mathrm{pH}$ axis at $\log \left[\mathrm{A}^{-}\right] /[\mathrm{HA}]=0$ gave the apparent $\mathrm{pKa}$ directly. All experiments were carried out at room temperature, $25 \pm 2^{\circ} \mathrm{C}$.

\section{RESULTS AND DISCUSSION}

With the exception of compound Ie $\left(m-\mathrm{NO}_{2}\right.$ substituent) the polarograms of the other members of the series studied displayed two polarographic waves (a) and (b) with equal wave-height in the potential range 0 to $-2.0 \mathrm{~V}$ (vs. SCE). Schematic polarograms of $10^{-4} \mathrm{~mol} \mathrm{~L}-1,40 \%$ $\mathrm{V} / \mathrm{V}$ ethanolic buffers in the $\mathrm{pH}$ range $\sim 2-11$ of Ia taken as a representative example is shown in Fig. 1. The morepositive $4 \mathrm{e}$ wave a predominates throughout the whole $\mathrm{pH}$ range with approximate constant wave height. On the other hand the more negative wave (b) at $\mathrm{pH}>5$ splits

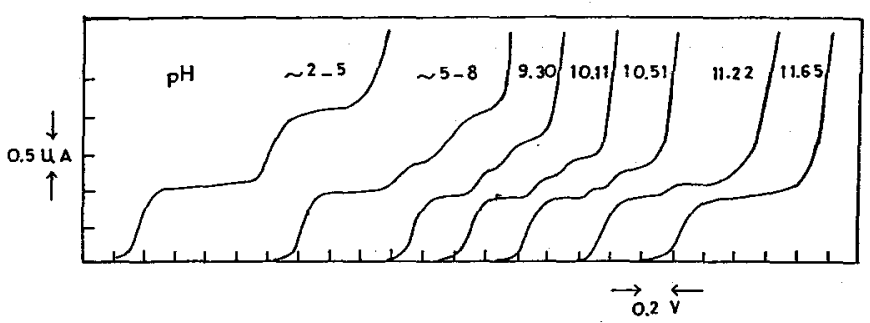

Fig. 1. Schematic representation of the polarograms of $10^{-4} \mathrm{M}$ 2-phenylazo-1,3-indandione-monozime $1_{\mathrm{a}}$ in $40 \% \mathrm{v} / \mathrm{v}$ ethanolic Britton-Robinson buffers.

into two waves $b_{1}$ and $\left(b_{2}\right)$ of equal heights and at still higher $\mathrm{pH}$ 's $(\mathrm{pH}>8)$ decreases in height and practically disappears at $\mathrm{pH} \geq 11$. Effects of varying mercury pressure and depolarizer concentration, at selected $\mathrm{pH}$ values indicate that the waves are mainly controlled by diffusion in the region where il is practically $\mathrm{pH}$ independnt. Test of irreversibility of these waves through logarithmic analysis $\left(\log \left(\mathrm{i} / \mathrm{i}_{1}-\mathrm{i}\right)\right.$ vs $\mathrm{f}(\mathrm{E})$ indicated that these processes are irreversible in nature as shown by the values of transition 
Table 2

Results of the statistical treatment of the $E_{1 / 2}-\sigma$ data (wave a) at different $\mathrm{pH}$ for compounds $\mathrm{I}_{\mathrm{a}-\mathrm{e} \text {. }}$

\begin{tabular}{ccccc}
\hline $\mathrm{pH}$ & $\mathrm{p}^{\mathrm{a}}$ & $\mathrm{r}^{\mathrm{b}}$ & $\sigma \mathrm{d}^{\mathrm{c}}$ & $\mathrm{n}^{\mathrm{d}}$ \\
\hline 4 & 0.256 & 0.970 & \pm 0.0156 & 5 \\
4 & 0.312 & 0.998 & \pm 0.0037 & 5 \\
4 & 0.387 & 0.995 & \pm 0.0097 & 5 \\
\hline
\end{tabular}

a) reaction constant b) correlation coefficient

c) standard deviation calculated by[22]

$\mathrm{S}= \pm\left[\left\{\mathrm{Sy}^{2}-(\mathrm{Sxy})^{2} / \mathrm{Sx}^{2}\right\} / \mathrm{n}-2\right]^{1 / 2}$

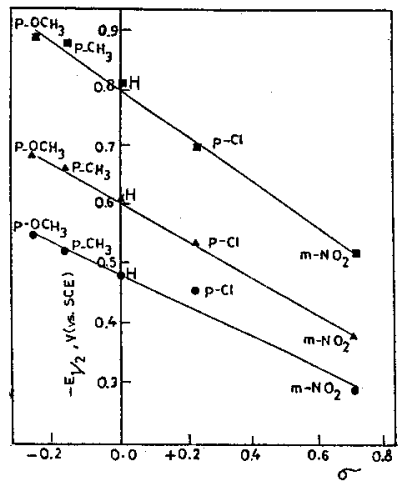

Fig. 4. $E_{1 / 2}-\sigma$ relation for 2-phenylazo, 1-3-indandionemonoxime derivatives at different $\mathrm{pH}$ values; $\mathbf{p H}$ $4 ; \Delta \mathrm{pH} 6 ; \boldsymbol{\mathrm { pH }} 9$.

As is clear good linearity was obtained with positive $r$ values varying between 0.256 and 0.387 . These values are in accordance with those reported in literature for compounds containing the azo $-\mathrm{N}=\mathrm{N}$ group[23]. That the nitro-group is reduced after wave (a) is confirmed here by the fact that the point for $m-\mathrm{NO}_{2}$ lies on the $\mathrm{E}_{1 / 2}-\sigma$ curve but not that for $m-\mathrm{NHOH}$ (reduced form of the nitro group), an indication that the reducible $-\mathrm{N}=\mathrm{N}$-centre is influenced by a nitro and not a hydroxylamine group.

On the other hand trials to correlate $\mathrm{pKa}$ values quoted in Table 1 to different $\sigma$ sets $\left(\sigma, \sigma^{0}, \sigma^{+}\right)$showed no dependence. This is to be anticipated since ionization arises at the oxime group (step 1 scheme 2) which is sufficiently far from the substituent in the phenyl ring.

\section{REFERENCES}

[1] Wawzonek, S., and J. D. Fredrickson, 1955. Polarographic behaviour of the azobenzene-hydrazone system. J. Amer. Chem. Soc. 77: 3985.

[2] Malik, W. U., V. K. Mahesh and R. N. Goyal, 1974. Polarographic reduction of some pyrimidine derivatives and the effect of substituents on their $\mathrm{E}_{1 / 2}$ values. J. Electroanal. Chem. 54: 411.

[3] Jain, R. and W. U. Malik, 1983. Application of the Hammet equation to the coupled products bketoesters with aryldiazonium chloride and the effect of double layer structure on $\mathrm{E}_{1 / 2}$ values. Indian J. Chem. 22A: 331 .
[4] Simon, H. and W. Moldehauer, 1967. Effect of Alkali on sugar oxazones and phenyl hydrazones. Chem. Ber. 100: 1949.

[5] Holleck, L. and G. Kazemifard, 1972 Protonation problems in electrode processes: Diazoamino-benzene and unsaturated ketones. J. Electroanal. Chem. 35: 369 .

[6] Sakla, A. B., H. M. Fahmy and M. A. Aboutabl, 1978. Polarographic behaviour of some p-nitorphenyl diazo aryl sulphides in aqueous media. J. Electroanal. Chem. 90: 261.

[7] Malik, W. U. and P. N. Gupta, 1974. Polarographic reduction of solochrone mordant dyes. J. Electroanal. Chem. 54: 417.

[8] Darwish, S., H. M. Fahmy, M. A. Abdel Aziz and A. A. El-Maghraby, 1981 . Polarography of some arylazothiohydantoin derivatives. J. Chem. Soc. Perk. II, 344.

[9] El-Nagdi, M. H. and H. M. Fahmy, 1977. Effect of substituents on the polarographic behaviour of a-aryl-hydrazonitriles: Further evidence for the mechanism of polarographic reduction aarylhydrazonitriles. J. Electroanla. Chem. 84: 149.

[10] Fahmy, M. H. and H. M. El-Nagdi, 1978. Polarographic behaviour of some a-phenylhydrazono bketonitriles. J. Electrochimica Acta, 23: 255.

[11] Fahmy, H. M., H. A. Daboun, K. Aziz and M. Abdel Azeem, 1983. Electrochemical behaviour of some thiazolo [3,2-a] Benzimidazol$3(2 \mathrm{H})$-one derivatives. J. Chem. Soc. Perkin Trans. II, 425.

[12] Helmy, Ahlam, M. A., 1993. Effect of electroactive group on reduction of the hydrazone linkage at the DME. Oriental J. Chem. 9(2): 188.

[13] Gudriniece, E. and G. Vanagas, 1958. Cyclic arylazo-b-diketones. Zh. Obscchch. Khim. 28: 58.

[14] Clark, W. M., 1928. The determination of hydrogen ions. Bailliers, Tindal \& Cox, London, 3rd. pp. $15,22,528$.

[15] Britton, H.T.S., 1962. Hydrogen Ions, Chapman and Hall, London, p. 365.

[16] Van Uitert, L. G. and G. G. Hass, 1953. Coordination compounds (I). detg. thermodynamic equilibrium constant in mixed solvents. J. Am. Chem. Soc., 75: 451.

[17] Lingane, J. J., 1945. Coulometric Analysis. J. Am. Chem. Soc. 67: 1916.

[18] Feigel, F., 1966. Spot Tests in Organic Analysis, Elsevier, Amsterdam, 7th. edn 
[19] Lund H. in M. M. Baaizer, 1973. Cathodic reduction of nitrocompounds in Organic Electrochemistry. Dekker, New York, ch. VII, 315.

[20] Mairanovski, B. G., 1962. Decrease of current on polarographic waves limited by chemical reaction. J. Electroanal. Chem., 4: 166.
[21] Ritchie, C. D. and W. F. Sagar, 1964. Examination of Structure. Reactivity Relation. Prog. Phys. Org. Chem., 2: 334.

[22] Jaffe, H. H., 1953. A Reexamination of the Hammett's Equation. Chem. Rev., 53: 1911.

[23] Zuman, P., 1967. Substituentt effects in organic polarography. Plenum Press, New York, pp. 43, 63. 